\title{
SPRINGBOK BEHAVIOUR AS AFFECTED BY ENVIRONMENTAL CONDITIONS IN THE KALAHARI
}

\author{
HEIN STAPELBERG \\ MARGARETHA W. VAN ROOYEN \\ Department of Plant Science \\ University of Pretoria \\ South Africa \\ JACOBUS DU P. BOTHMA \\ Centre for Wildlife Management \\ University of Pretoria \\ South Africa \\ MICHAEL J. VAN DER LINDE \\ HENDRIK T. GROENEVELD \\ Department of Statistics \\ University of Pretoria \\ South Africa
}

Correspondence to: Margaretha W. van Rooyen

e-mail: gretel.vanrooyen@up.ac.za

Postal Address: Department of Plant Science, University of Pretoria, Pretoria 0002, South Africa

\begin{abstract}
Springbok behavioural ecology in the Kalahari was examined with the use of public questionnaires and field forms. Springbok favoured grass and forbs overall more than shrubs and trees, but diet selection was influenced by time of day and season. Feeding was the most common activity and the frequency of occurrence varied during the day and between seasons. Weather and microhabitat conditions were found to have a significant effect on the feeding behaviour. Springbok fed in direct sunlight in the mornings and moved into the shade during the afternoon. More time was spent feeding in the shade during the warmer months than during the colder months, especially under northerly to northeasterly wind directions. Natural licks were commonly utilised. Herd sizes were found to increase during the cold-dry season and decrease during the hot-wet season. Springbok and blue wildebeest appeared to avoid competition by niche separation. The study showed that springbok behaviour was significantly affected by environmental conditions. These results imply that changes in climatic conditions, such as those predicted by climate change, or changes in vegetation structure due to degradation, can negatively affect springbok behaviour.
\end{abstract}

Keywords: Antidorcas marsupialis, climate, feeding ecology, questionnaire, seasonality

The Kalahari plays host to a range of herbivores of which springbok Antidorcas marsupialis (Zimmermann, 1780) are characteristic. It has even been suggested that the Kalahari springbok be declared a distinct subspecies (Bigalke 1970, Peters \& Brink 1992). Springbok morphology and anatomy have been studied in detail (Skinner \& Louw 1996), but there are few indepth ecological studies of springbok in the Kalahari. Studies on the morphology and anatomy of the springbok show that they are well suited to arid areas and are able to cope well with changing environmental pressures (Louw \& Seely, 1982; Mills \& Retief, 1984; Spinage \& Matlhare, 1992; Skinner \& Louw, 1996; Skinner \& Moss, 2004). Springbok are selective feeders (Bothma et al. 2002) and the quality of their diet is a significant driving force behind their behaviour and movements (Mills \& Retief 1984). They have an exceptionally high annual population growth of 35 to $45 \%$ (Mills \& Haagner, 1989; Conroy 2005).

Recent declining springbok populations in South Africa have been reported from the Kalahari, while other areas such as the Karoo have shown a significant increase in recent times (Skinner \& Moss 2004). Historical records describe numerous massive migrations (Eloff 1961, Child \& Le Riche 1969) which are well reviewed by Skinner (1993). However, the population numbers of springbok have been declining in the Kalahari over the past 50 years, and rapidly so in the past 20 years (Skinner, pers. comm.; Engelbrecht, pers. comm.; Skarpe, 2001; Skinner \& Moss, 2004). Studies of sex ratios within springbok populations (Bednekoff \& Ritter 1997) and of morphometrics and reproduction (Skinner et al. 1996) do not give any clues to the reason for the decline in numbers, and no significant increase in depredation or predator numbers has been noticed.

The focus of this paper is on the activities of springbok on the South African side of the Kgalagadi Transfrontier Park, the Kalahari Gemsbok National Park. The hypothesis that was put forward was that springbok behaviour, in particular feeding and food selection, is significantly affected by environmental and seasonal conditions. To test the hypothesis, data were gathered by means of public questionnaires and researcher observations.

\section{STUDY AREA}

The Kalahari consists of the largest continuous stretch of sand in the world, located more or less diagonally across southern to central Africa (Van Rooyen 2001). The southwestern Kalahari is considered a relatively unspoilt, ecologically fragile, arid savanna (Van Rooyen \& Van Rooyen 1998). The largest conservation unit within the Kalahari ecosystem, the Kgalagadi Transfrontier Park, is shared across the borders of South Africa and Botswana (Van Rooyen 2001). The present study was carried out on the South African side of the park, called the Kalahari Gemsbok National Park (between $24^{\circ} 15^{\prime} \mathrm{S}$ and $26^{\circ} 30^{\prime} \mathrm{S}$, and $20^{\circ} 00^{\prime} \mathrm{E}$ and $20^{\circ} 45^{\prime} \mathrm{E}$ ), an area that covers some $9600 \mathrm{~km}^{2}$ (Jackson 1995). 
The southwestern Kalahari consists mainly of red sand dunes that are underlain by calcrete. The two main dry riverbeds of the Auob and the Nossob Rivers (Jackson 1995; Van Rooyen \& Van Rooyen, 1998), cut through the dunes and converge just north of the Twee Rivieren Rest Camp. Among the dunes are some dispersed pans, increasing in abundance from around the centre of the park northwards and eastwards into Botswana.

The Kalahari receives the majority of its rain during summer and has a highly erratic (Skarpe, 1986; Tyson, 1986) annual rainfall of around $180 \mathrm{~mm}$ in the southwest to $400 \mathrm{~mm}$ in the northeast. During the study period, the mean rainfall amounted to $213.6 \mathrm{~mm}$ over 19 months across all weather stations within the Kalahari Gemsbok National Park (data supplied by the Kgalagadi Transfrontier Park 2004). Three ecological seasons occur, namely the hot-wet season (January to April), cold-dry season (May to August) and hot-dry season (September to December) (Leistner 1967, Mills \& Retief 1984, Van Rooyen \& Van Rooyen 1998). The temperature range is immense, with recorded winter lows of around $-10^{\circ} \mathrm{C}$ and summer highs of around $45^{\circ} \mathrm{C}$ (Van Rooyen et al. 1990).

\section{MATERIALS AND METHODS}

Properly designed questionnaires can be used as an effective and affordable tool for gathering large amounts of data within a relatively short period (Hague 1993). However, the use of questionnaires is not without flaws and difficulties and those discovered during the course of this study are analysed in Stapelberg (2007). Constructing meaningful and interpretable questions is a complex process and requires careful word selection to ensure that the questions are asked in such a way that they are fully understood by the respondent. Whenever a public questionnaire is used to collect data in conjunction with a researcher, public respondents' answers should be checked for differences against the researcher's answers and ground-truthed, where possible. Only once these differences are described and understood can the data be used (Stapelberg 2007). Properly applied statistics are invaluable for filtering such data.

A public questionnaire and field data sheet were compiled of observable variables relating to springbok behaviour (Appendix A). The questions consisted of factual information (such as date and time), closed format questions (where choices were given) as well as open-ended questions about animal activity. The questionnaire was distributed to staff and visitors of the Kalahari Gemsbok National Park over a period of 13 months. During this time, informative talks were also held at the main rest camp, Twee Rivieren, explaining the project and the questionnaire. One questionnaire per herd (solitary springbok were also considered as a herd) had to be completed and collection boxes were positioned at the reception office of every camp and emptied periodically. During the same period, the researcher collected data by using a field data sheet that was based on the public questionnaire. The researcher also recorded some additional variables (Appendix A).

Observations were mostly conducted at random within strips (Bothma 2002), and were done from a vehicle en route between destinations. Most observations were made within the dry riverbeds of the Nossob and Auob Rivers, since this is where the springbok tend to congregate and most of the tourist routes in the park are. Visibility varied, but was generally up to around $150 \mathrm{~m}$ on either side of the vehicle. Binoculars and/or a spotting-scope were used when necessary.

Data were transformed into numerical codes and these numerical codes were captured into a matrix using Microsoft Excel. Data were classified into ranges or categories wherever it best suited the analytical model or question at hand. All analyses were done using SAS software (SAS ${ }^{\circledR}$ Software Version 8.2, SAS Institute Inc., SAS Campus Drive, Cary, NC 27512, USA). Chisquare tests for independence were conducted to examine the independence of variables. The hypotheses of dependence were expressed by $p$-values, where $p \leq 0.05$ indicated that the variables being tested were independent. Generalised linear models were also used to examine the data, incorporating either classed or continuous independent variables. In most cases the independent variable used in the generalised linear models was time. Repeated measures analyses of variance were also used in generalised linear models to consider differences between dependent variables at independent variable intervals. Logistic procedures were used to calculate odds ratios for binary variables. Where necessary, regression analyses were used to clarify trends. Where the means for collective data were used, these were calculated as least square means so as to equalise the data for a more accurate mean representation. Analyses of variance (ANOVA) were used to distinguish the various attributes of the variables.

This paper explores daily and seasonal trends in a selection of springbok activities collected by means of the questionnaire. The analysis of activity data generally involved two steps. First, the activity data were compared with and without the influence of a specified variable to investigate the effect of said variable. Thereafter, the means of the activity data were determined according to each class of the specified variable and compared with each other.

To investigate the effect of rainfall on herd size, rain was accepted as being present only when a minimum of $10 \mathrm{~mm}$ had fallen in a particular month. This was to ensure that a sufficient amount of water had been received to induce vegetation sprouting. The generalised linear model incorporated a lag effect in order to accommodate a response time for vegetation after the occurrence of rain. A total of 17 rainfall stations are located in the Kalahari Gemsbok National Park. A georeferenced grid was created to match specific rainfall stations with herd locations.

\section{RESULTS AND DISCUSSION}

Two thousand questionnaires were distributed and 955 (47.7\%) were returned. The researcher completed $31.7 \%$ and public respondents the balance $(68.3 \%)$. Observations lasted from one to more than ten minutes, most observations not continuing more than three minutes.

\section{Food item selection}

Food item selection was considered at growth form level. Observations were made of springbok feeding either on grass/forbs, shrubs or trees at different times of the day to determine whether there was a change in food item selection during the course of the day.

Feeding on grass/forbs, shrubs and trees could not be explained effectively by using time as a continuous independent variable. Even when time was reclassified into hourly categories a linear model could not be fitted appropriately for feeding on grass/forbs $\left(\mathrm{R}^{2}=0.03 ; \mathrm{df}=12\right)$, shrubs $\left(\mathrm{R}^{2}=0.02 ; \mathrm{df}=12\right)$ or trees $\left(\mathrm{R}^{2}=0.01 ; \mathrm{df}=12\right)$. Springbok favoured grass/forbs overall more than shrubs and trees (Figure 1). The percentage of the herd feeding on grass/forbs reached a maximum in the early morning from > 07:00-08:00 to > 09:00-10:00. This trend is supported by other research (Nagy \& Knight 1994) and is likely related to the increased moisture content of grass during early morning (Taylor 1968). Tree leaf consumption remained low throughout the day. Shrubs were consumed at a lower rate the later in the day it became, possibly due to decreasing moisture content. Compared to grass/forb consumption, the relative consumption of shrubs reached a peak at >11:00-12:00 and again at $>$ 15:00-16:00.

Diet selection of springbok is affected by season. An investigation 


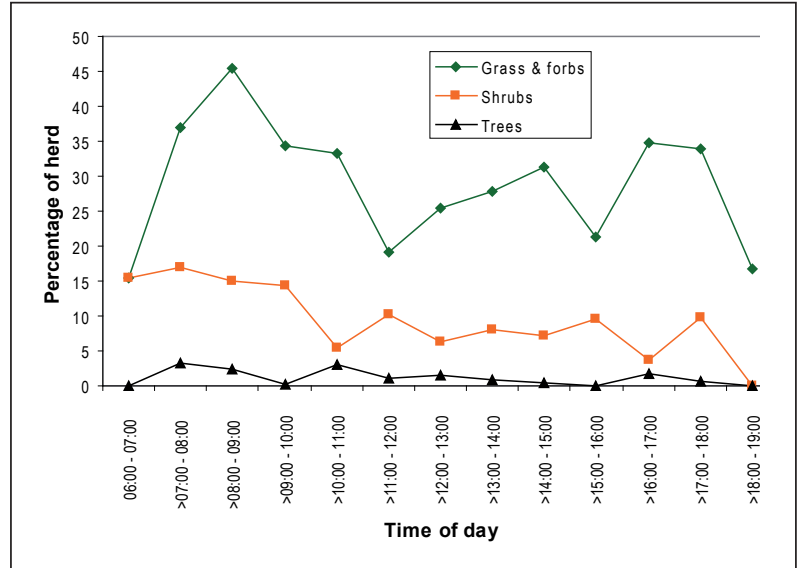

FIGURE 1

Mean percentage of springbok herd feeding on grass/forbs, shrubs and trees at hourly intervals from November 2002 to May 2004 in the Kalahari Gemsbok National Park

into the seasonal changes in nutrient content of springbok food plant species in the Kalahari showed that the crude protein and phosphorus levels were especially low during the cold-dry season (Stapelberg et al. in press). Browse species had a higher crude protein and phosphorus content than grass species. Consequently, springbok could consume a higher quality diet if they changed their feeding strategy to include more browse than grasses in their diet during the winter months.

Springbok were observed to eat Rhigozum trichotomum leaves throughout the year, but especially so when the plants were freshly sprouting. This supports observations by Bothma (1971), who described a rapid response by springbok to newly emerging green sprouts of $R$. trichotomum. This species was not specifically selected as food during times when a diversity of fresh plant growth was present, except when in flower. When flowering, springbok were observed to move through R. trichotomum thickets, only feeding on the flowers. It has also been reported that springbok consume plant underground storage organs as a source of moisture (Williamson 1987), but that could not be confirmed during the present study.

\section{Nocturnal feeding}

No data were collected on nocturnal feeding by public respondents because of tourist travel restrictions, and the data collected by the researcher were mostly qualitative. Springbok were observed to feed at night during all three seasons of the year. Two peak feeding times were reported during the hot-dry season as opposed to one in the cold-dry and hot-wet seasons. Feeding periods were also longer during the two dry seasons than in the wet season. These observations could indirectly be seen as supporting the hypothesis that animals feed on plant material at night because of elevated moisture levels. Nocturnal feeding behaviour could be a form of depredation prevention by the herd through having vigilant individuals awake while some continue resting (Siegfried, 1980; Treves, 2000).

\section{Licks}

'Natural licks', i.e. areas where animals lick hardened, clayish soil, occur in several places in the Kgalagadi Transfrontier Park. These licks are mostly associated with pans (Van Rooyen et al. 1994). Kalahari springbok make regular use of natural licks, and clear evidence of the presence of clay has been found in the guts of springbok that were shot close to pans in the Kalahari in Botswana (Bergström \& Skarpe 1999). In the present study, utilisation of such licks was especially prominent around the Kannaguass waterhole in the Nossob riverbed. Springbok utilise licks presumably to supplement their dietary requirements and are reportedly sometimes attracted to artificial waterholes more

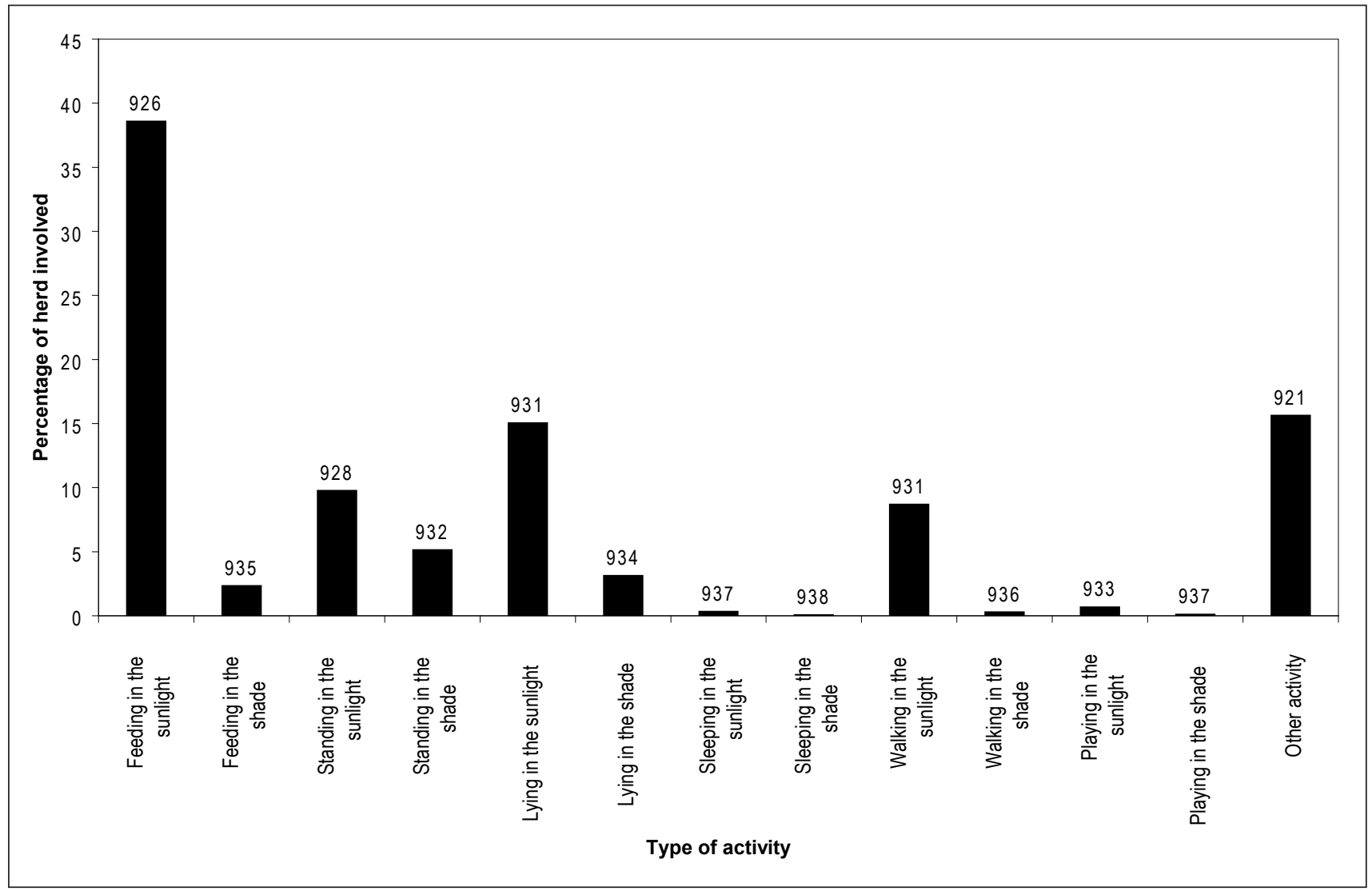

FIGURE 2

Mean percentage of springbok herd involved in different activities, over all time periods, during the study period from November 2002 to May 2004 in the Kalahari Gemsbok National Park. The "Other activity" category contains a collection of activities, all of which were recorded infrequently. The value on each bar in the graph indicates the sample size being used to calculate the percentage for that particular activity 
TABLE 1

P-values of comparative tests between sets of two variables (activities) to examine independence of the frequency of different activities in springbok herds from November 2002 to May 2004 in the Kalahari Gemsbok National Park. Statistical independence is where $\mathrm{p} \leq 0.05$

\begin{tabular}{|c|c|c|c|c|c|c|c|c|c|c|c|c|c|c|}
\hline & 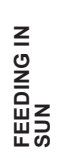 & & 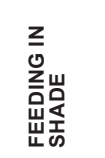 & 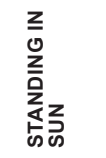 & 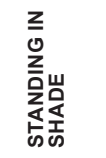 & 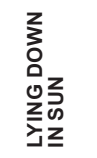 & 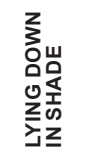 & 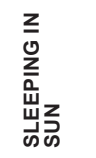 & 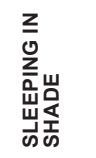 & 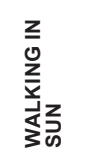 & 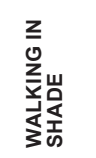 & 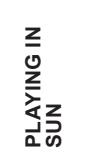 & 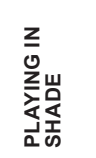 & 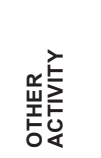 \\
\hline Feeding in sun & & - & $<0.0001$ & $<0.0001$ & $<0.0001$ & $<0.0001$ & $<0.0001$ & $<0.0001$ & $<0.0001$ & $<0.0001$ & $<0.0001$ & $<0.0001$ & $<0.0001$ & $<0.0001$ \\
\hline Feeding in shade & & & - & 0.0051 & 0.2654 & 0.0002 & 0.7123 & 0.0969 & 0.0462 & 0.0280 & 0.0842 & 0.2745 & 0.0493 & $<0.0001$ \\
\hline Standing in sun & & & & - & 0.1035 & 0.2074 & 0.0173 & $<0.0001$ & $<0.0001$ & 0.6365 & $<0.0001$ & 0.0002 & $<0.0001$ & 0.2406 \\
\hline Standing in shade & & & & & - & 0.0074 & 0.4442 & 0.0150 & 0.0074 & 0.2796 & 0.0141 & 0.0434 & 0.0089 & 0.0005 \\
\hline Lying down in sun & & & & & & - & 0.0005 & $<0.0001$ & $<0.0001$ & 0.1075 & $<0.0001$ & $<0.0001$ & $<0.0001$ & 0.6604 \\
\hline Lying down in shade & & & & & & & - & 0.0564 & 0.0275 & 0.0690 & 0.0535 & 0.1618 & 0.0333 & $<0.0001$ \\
\hline Sleeping in sun & & & & & & & & - & 0.2869 & 0.0006 & 0.9124 & 0.3252 & 0.5393 & $<0.0001$ \\
\hline Sleeping in shade & & & & & & & & & - & 0.0003 & 0.5665 & 0.0968 & 0.6795 & $<0.0001$ \\
\hline Walking in sun & & & & & & & & & & - & 0.0005 & 0.0016 & 0.0003 & 0.0712 \\
\hline Walking in shade & & & & & & & & & & & - & 0.3112 & 0.6864 & $<0.0001$ \\
\hline Playing in sun & & & & & & & & & & & & - & 0.1353 & $<0.0001$ \\
\hline Playing in shade & & & & & & & & & & & & & - & $<0.0001$ \\
\hline Other activity & & & & & & & & & & & & & & - \\
\hline
\end{tabular}

for the licks than the water itself (Knight \& Knight-Eloff, 1988; Van Rooyen et al., 1994). It is unclear whether this was the case in the present study, as springbok were observed to drink water intermittently while also utilising licks. The licks that were observed all occurred within the piosphere zone (Jeltsch et al. 1997) around waterholes, and their frequent use could therefore have a degrading effect on the vegetation around waterholes.

\section{Springbok feeding times}

Although only 21 activities were listed in the questionnaire, up to 31 different activities were specified by respondents. The mean percentage of springbok involved in these activities over all time periods during the whole study period showed that feeding in sunlight occurred most often (38.6\%, Figure 2).

Six of all the recorded activities related directly to feeding. Neither feeding in the sunlight $\left(\mathrm{p}=0.220 ; \chi^{2}=0.003 ; \mathrm{df}=2\right)$ nor feeding in the shade $\left(\mathrm{p}=0.150 ; \chi^{2}=0.004 ; \mathrm{df}=2\right)$ showed any significant changes in frequency of occurrence across different seasons. When these two activities were compared with the rest of the activities by Analysis of Variance of Contrast Variables, it was found that feeding in the sunlight occurred significantly more frequently than all other activities (Table 1). Frequency of feeding in the shade $(2.3 \%)$ was also significantly different from most other activities, but not from standing in the shade (5.1\%; $\mathrm{p}=0.265 ; \mathrm{df}=1)$, lying down in the shade $(3.1 \% ; \mathrm{p}=0.712 ; \mathrm{df}=1)$, sleeping in the sunlight $(0.3 \% ; \mathrm{p}=0.097 ; \mathrm{df}=1)$, walking in the shade $(0.3 \% ; \mathrm{p}=0.084 ; \mathrm{df}=1)$ and playing in the sunlight $(0.7 \%$; $\mathrm{p}=0.2745 ; \mathrm{df}=1)($ Figure 2; Table 1).

The lack of a significant difference in the frequency of shaderelated activities (feeding, standing, lying down and walking) indicated that the time spent in the shade was divided equally between these activities. Springbok herds were often observed to rest in the shade during the heat of the day. During such resting periods, different animals in the herd would be involved in different activities, such as standing, walking and feeding. The main objective of spending time in the shade other than feeding is assumed to be to rest.

Daily trends of all activities are presented in Figure 3. Fewer springbok were observed to be feeding in the sunlight the later in the day it became up to approximately 16:00 (Figure 3a). Significantly more springbok per herd were feeding in the sunlight at early morning (> 07:00-08:00) than at mid-morning $(>10: 00-11: 00)(\mathrm{p}=0.0002 ; \mathrm{df}=1)$ or mid-afternoon $(>15: 00-$ $16: 00)(\mathrm{p}<0.0001 ; \mathrm{df}=1)$. In contrast, a significantly larger percentage of the herd was feeding in the shade at midday > 12:00-13:00 than at > 09:00-10:00 $(\mathrm{p}=0.032 ; \mathrm{df}=1)$.
Activities that reached their peak frequency in the hour during sunrise included sleeping in direct sunlight (Figure 3d) and playing in the shade (Figure 3f). Feeding and playing in direct sunlight (Figures $3 a$ and $3 \mathrm{f}$ ) reached their peak frequency during early morning, while lying down and playing in the shade (Figures $3 \mathrm{c}$ and $3 \mathrm{f}$ ) occurred at their lowest frequency then. Lying down in direct sunlight (Figure 3c) reached a peak during the late morning, while feeding in the shade (Figure 3a) and standing in direct sunlight (Figure $3 b$ ) had a low frequency of occurrence then. Activities that peaked at midday included feeding in the shade (Figure 3a) and standing in direct sunlight (Figure 3b), while feeding in direct sunlight (Figure 3a) occurred at its lowest frequency. During early afternoon standing and lying down in the shade (Figures $3 \mathrm{~b}$ and $3 \mathrm{c}$ ) and walking in direct sunlight (Figure 3e) had a high frequency of occurrence, whereas lying down in direct sunlight (Figure 3c) did not occur often then.

\section{Feeding by season}

A generalised linear model was used to test the null hypothesis that the frequency of an activity in springbok herds did not differ significantly between the three different seasons. The results showed that none of the feeding-related activities produced either a good linear model fit or a significant dependence when analysed by season $\left(p>0.130\right.$ and $R^{2}<0.005$ in all cases). Although fewer animals were found to feed in the direct sunlight in the hot-dry season than in the hot-wet season, this difference was not significant $\left(p=0.087 ; R^{2}=0.003\right)$. It appeared that more animals fed in the shade during the hotdry season compared with the cold-dry season, but again this difference was not significant $\left(p=0.075 ; R^{2}=0.004\right)$ (Figure 4).

\section{The effect of wind on feeding \\ Wind strength}

Analyses relating to wind strength were based on relatively few observations ( $\mathrm{n}=97)$. Nonetheless, they showed a few notable results. None of the feeding activities seemed to be influenced by wind strength ( $p>0.160$ in every case), nor did the feeding activities differ significantly from each other with the overall effect of wind strength taken into account $(\mathrm{p}=0.352 ; \mathrm{df}=3)$. However, standing in the shade was positively linearly related to wind strength $\left(R^{2}=0.225 ; p<0.0001\right)$, although the fit was poor.

\section{Wind direction}

A larger percentage of the herd fed in the sunlight when there was no wind, a southeasterly, or a random wind than when there was a northerly wind $(p=0.022, p=0.043$ and $p=0.016$ 


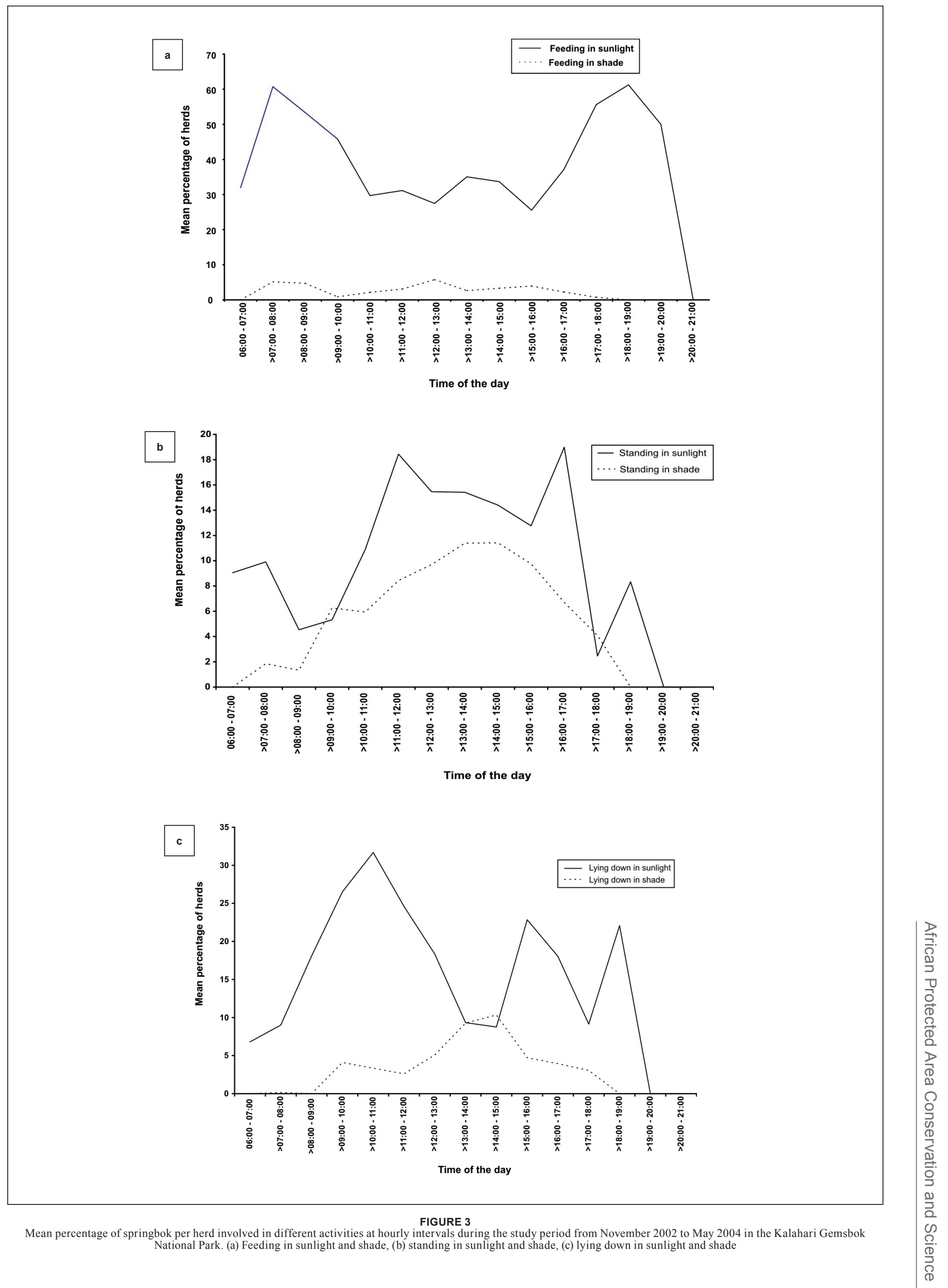



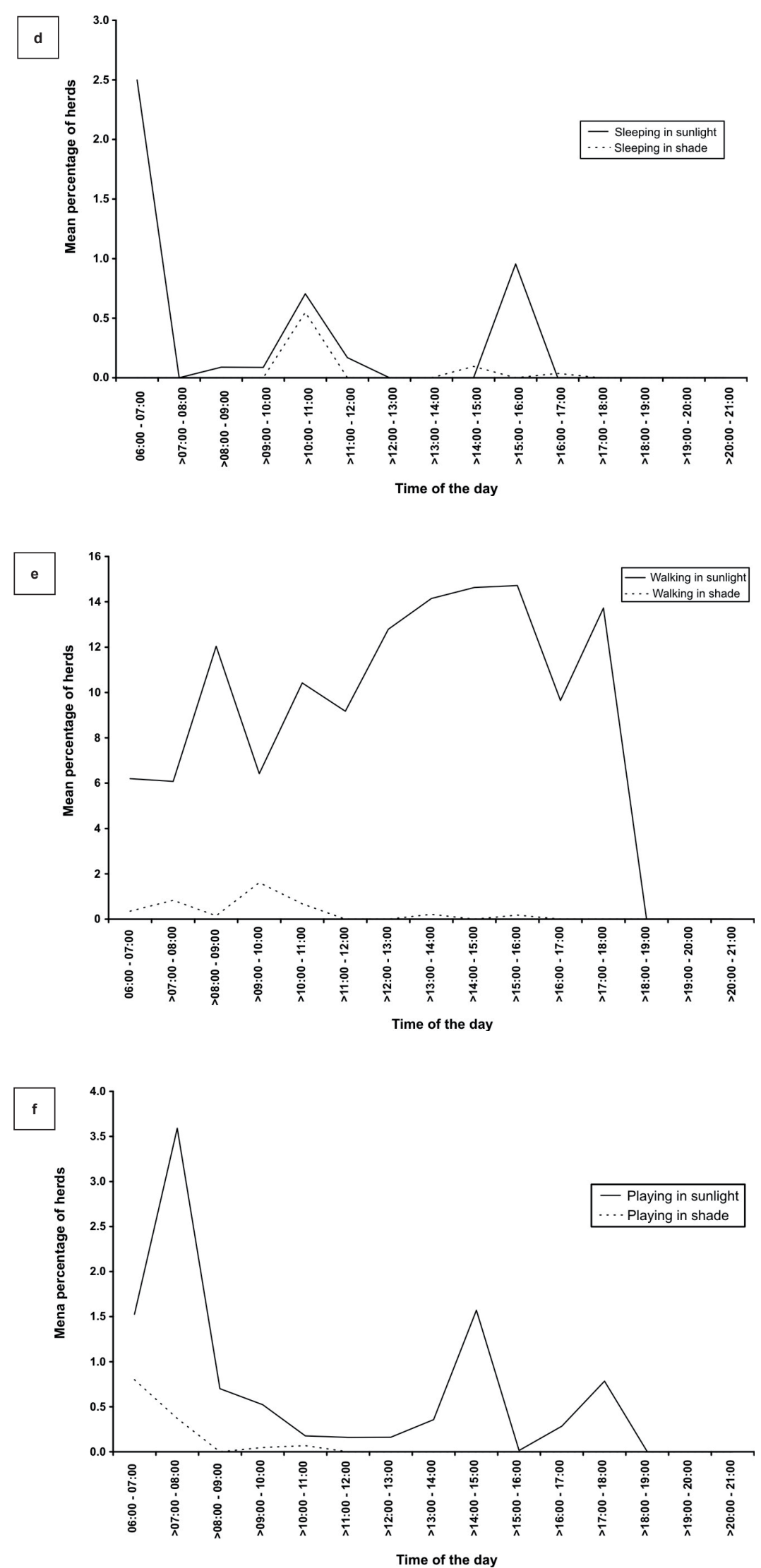

FIGURE 3 (CONT...

FIGURE 3 (CONT...)
Mean percentage of springbok per herd involved in different activities at hourly intervals during the study period from November 2002 to May 2004 in the Kalahari Gemsbok National Park: (d) sleeping in sunlight and shade, (e) walking in sunlight and shade, and (f) playing in sunlight and shade 


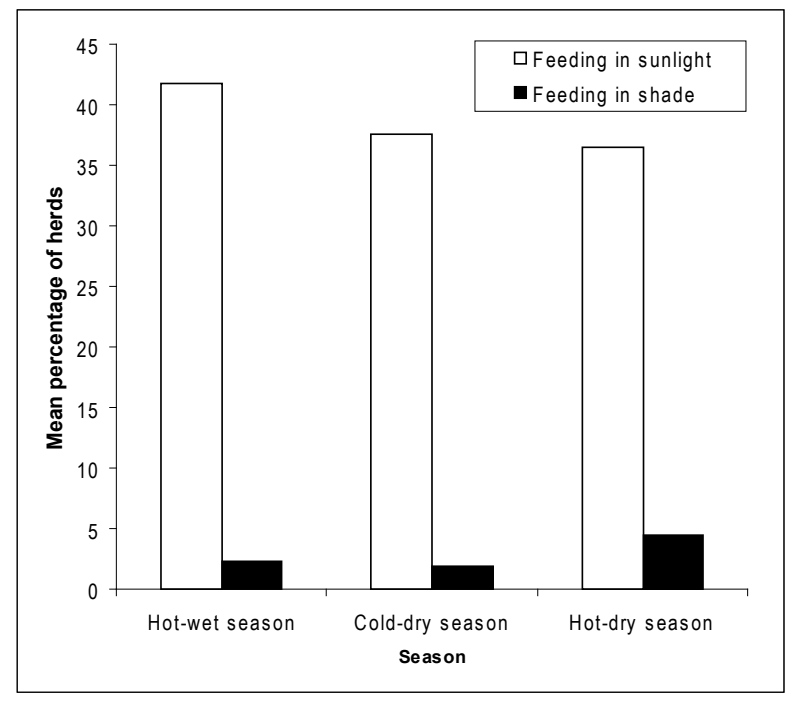

FIGURE 4

Mean percentage of springbok herd feeding in sunlight and shade respectively during the hot-wet, cold-dry and hot-dry seasons from November 2002 to May 2004 in the Kalahari Gemsbok National Park

respectively). A larger percentage of the herd was observed feeding in the shade in northeasterly wind conditions than in northwesterly conditions or in no wind $(p=0.009$ and $p=0.022$ respectively). This may suggest that winds from the north to northeast are hotter winds that add to thermoregulation stress in springbok. Springbok may subsequently adapt by changing their feeding behaviour to specifically feed in the shade.

\section{Herd size and rainfall}

Rainfall is a key environmental factor in the southern Kalahari (Van Rooyen et al. 1990) and consequently, the effect of rainfall on herd size was examined. Herd sizes varied between seasons and months. Significantly larger mean herd sizes were recorded during months of no rain, but when it had rained in the previous month, compared with no rain for two consecutive months $(p=0.047)$; rain during both consecutive months $(\mathrm{p}=0.014 ; \mathrm{df}=3)$; or rain during the surveying month, but not the previous month $(\mathrm{p}=0.012)$ (Table 2$)$.

The largest mean herd sizes were recorded during June 2003 at 102.1 animals $(n=25)$ and the smallest during November 2002 at 9.1 individuals $(n=57)$ (Table 3). The largest herd recorded during the study period consisted of 476 springbok found in the far northern part of the Nossob riverbed, close to Kannaguass waterhole, in April 2003. Mean herd sizes by season were largest during the cold-dry season (40 springbok, $\mathrm{n}=329$ ), intermediate during the hot-wet season (35 springbok, $\mathrm{n}=294$ ) and smallest during the hot-dry season (19 springbok, $\mathrm{n}=326$ ). These springbok herd sizes coincide roughly with those reported by other researchers in the same area as having a peak from February to May and a trough from October to November (Mills \& Retief 1984, Jackson et al. 1993).

Springbok herd sizes therefore increased during the colddry season and decreased during the hot-dry season. This phenomenon appeared to be linked to specific rainfall patterns rather than to rigid seasonal boundaries. These results also

\section{TABLE 2}

Relationship between herd size of springbok and rainfall in the Kalahari Gemsbok National Park during the study period from November 2002 to May 2004. Rainfall in the current and previous months were noted as present (1) or absent (0) respectively. Values with the same superscript do not differ significantly $(\mathrm{p}>0.05)$

\begin{tabular}{lll}
\hline PREVIOUS MONTH & CURRENT MONTH & MEAN HERD SIZE \\
\hline 0 & 0 & $40.915^{\mathrm{a}}$ \\
0 & 1 & $24.189^{\mathrm{a}}$ \\
1 & 0 & $71.413^{\mathrm{b}}$ \\
1 & 1 & $15.099^{\mathrm{a}}$ \\
\hline
\end{tabular}

TABLE 3

Mean herd sizes of springbok by month for the period from November 2002 to May 2004 in the Kalahari Gemsbok National Park

\begin{tabular}{|c|c|c|c|}
\hline SEASON & $\begin{array}{l}\text { MONTH AND } \\
\text { YEAR }\end{array}$ & $\begin{array}{l}\text { MEAN HERD SIZE } \pm \\
\text { STANDARD DEVIATION }\end{array}$ & $\begin{array}{l}\text { NUMBER OF } \\
\text { OBSERVATIONS }\end{array}$ \\
\hline \multirow[t]{2}{*}{ Hot-dry } & November 2002 & $9.1 \pm 20.97$ & 57 \\
\hline & December 2002 & . & . \\
\hline \multirow[t]{4}{*}{ Hot-wet } & January 2003 & . & . \\
\hline & February 2003 & . & . \\
\hline & March 2003 & $43.7 \pm 76.67$ & 73 \\
\hline & April 2003 & $31.1 \pm 69.36$ & 209 \\
\hline \multirow[t]{4}{*}{ Cold-dry } & May 2003 & $53.4 \pm 83.43$ & 58 \\
\hline & June 2003 & $102.1 \pm 85.47$ & 25 \\
\hline & July 2003 & $56.2 \pm 75.07$ & 48 \\
\hline & August 2003 & $23.0 \pm 36.45$ & 180 \\
\hline \multirow[t]{4}{*}{ Hot-dry } & September 2003 & $17.2 \pm 25.47$ & 141 \\
\hline & October 2003 & $13.5 \pm 21.05$ & 51 \\
\hline & November 2003 & $34.6 \pm 59.88$ & 73 \\
\hline & December 2003 & $29.7 \pm 13.25$ & 4 \\
\hline \multirow[t]{4}{*}{ Hot-wet } & January 2004 & . & . \\
\hline & February 2004 & $49.2 \pm 76.48$ & 10 \\
\hline & March 2004 & $74.0 \pm 36.77$ & 2 \\
\hline & April 2004 & . & . \\
\hline Cold-dry & May 2004 & $31.9 \pm 55.63$ & 18 \\
\hline Total & . & $40.6 \pm 25.26$ & 949 \\
\hline
\end{tabular}

support the results of other studies (Bigalke 1972, Nagy \& Knight 1994, Bergström \& Skarpe 1999), and are probably due to the concurrence of lambing with rainfall. Bothma and Mills (1977), although using total counts instead of herd sizes, reported similar trends.

\section{Springbok and other animals}

Springbok are known to associate with blue wildebeest Connochaetes taurinus and gemsbok Oryx gazella (Skinner \& Louw 1996). However, during the present study period, blue wildebeest were either not present or were some distance away from the springbok herds studied in $88.5 \%$ of all observations. Blue wildebeest were sometimes witnessed to feed in conjunction with springbok, as if moving in a convoy. The distance from the blue wildebeest to the springbok herds was mostly recorded as being at $>50 \mathrm{~m}$ away $(5.2 \%)$, followed by $0-20 \mathrm{~m}$ away $(4.0 \%)$ and then by $21-50 \mathrm{~m}$ away $(2.3 \%$; $\mathrm{p}=0.060$; $\chi^{2}=7.4 ; \mathrm{df}=3$ ). Gemsbok proximities showed similar trends $\left(p=0.007 ; \chi^{2}=9.86 ; \mathrm{df}=2\right)$. Moreover, gemsbok were close to springbok more often than blue wildebeest.

According to Knight (1995), the blue wildebeest grazes at a higher level than the springbok and seems to precede springbok as low-level grazer. Qualitative observations confirmed this during the study period. Blue wildebeest have wide muzzles that are suited for grazing relatively close to the ground. Springbok have narrow muzzles suited for selective feeding (Skinner \& Louw 1996). The results of the present study suggest that springbok and blue wildebeest coexist in the Kalahari by avoiding competition through niche separation. They also suggest that although these two animal types occur together, springbok and blue wildebeest more often prefer not to feed in close proximity. A similar situation occurs between plains zebra Equus quagga, white-bearded wildebeest Connochaetes taurinus subsp. mearnsi and Thomson's gazelle Gazella thomsoni in the Serengeti in Tanzania (Sinclair \& Norton-Griffiths 1982). The Thomson's gazelle is morphologically similar to the springbok and is also a selective feeder. However, in their study, Sinclair and Norton-Griffiths (1982) concluded that the white-bearded 
wildebeest were regulating the Thomson's gazelle in the Serengeti through competition. Competition can therefore not be excluded as a factor regulating the springbok population in the Kalahari and more research on this aspect is required.

Gemsbok are considered roughage feeders and the majority of their diet consists of grass. It is not a strongly territorial animal and is believed to be fairly water-independent (Bothma 2002). Few similarities between the preferred plant species selected by springbok and gemsbok could be found in the literature (Leistner 1959).

\section{CONCLUSIONS}

The diet of Kalahari springbok is highly variable and diet selection is influenced by season and time of day. Kalahari springbok make regular use of natural licks, presumably to supplement their dietary requirements. This may have an environmentally degrading effect, especially due to lick locations, but may not be so serious as to require conservation efforts. Compared to other activities, feeding was the most important activity of springbok and had the highest frequency of occurrence during all seasons and at all times of the day in the present study. Climate and weather conditions were found to have a significant effect on the feeding behaviour, as did shade and direct sunshine. In general, the springbok fed in direct sunlight in the mornings and the frequency of feeding in the shade increased towards midday. They also spent more time feeding in the shade during the hot-dry season than during the cold-dry and hot-wet ones. Wind strength did not affect feeding behaviour, although wind direction did Springbok fed in the shade more often under northerly and northeasterly wind directions. Herd sizes were significantly related to specific rainfall patterns rather than to rigid seasonal boundaries. The ecological relationship between springbok and blue wildebeest was investigated and evidence was found of competition avoidance through niche separation.

The study showed that springbok behaviour was significantly influenced by time of day, season, wind and rainfall and the hypothesis that environmental conditions affect springbok behaviour significantly can confidently be accepted. The presence of large trees that provide shade was important as these seemed to afford some protection against the extreme heat in the middle of the day or against hot winds from the north to northeast. These results imply that changes in climatic conditions, such as those predicted by climate change, or changes in vegetation structure due to degradation, will affect springbok behaviour. The information that was gained from this research project gives an overview of the current springbok ecology in the Kalahari; it serves as a valuable benchmark for future studies on springbok behaviour; and provides background knowledge to generate hypotheses on possible reasons for the decline in springbok numbers that can be investigated in future studies.

\section{ACKNOWLEDGEMENTS}

We thank Camelbak International for their support and express our gratitude to the Kalahari Gemsbok National Park for approving this project and the University of Pretoria and the National Research Foundation (GUN 2053522) for their financial support.

\section{REFERENCES}

Bednekoff, P.A. \& Ritter, R.C. 1997. Adult sex ratio of a wild population of Springbok (Antidorcas marsupialis) at Nxai pan, Botswana. African Journal of Wildife Research, 27: 22-26.

Bergström, R. \& Skarpe, C. 1999. The abundance of large wild herbivores in a semi-arid savanna in relation to seasons, pans and livestock. African Journal of Ecology, 37(1): 12-26.
Bigalke, R.C. 1970. Observations on springbok populations. Zoologica Africana, 5: 59-70.

Bigalke, R.C. 1972. Observations on the behaviour and feeding habits of springbok, Antidorcas marsupialis. Zoologica Africana, 7: 333-359.

Bothma, J. du P. 1971. Notes on river habitat use by larger ungulates in the Kalahari Gemsbok National Park. Koedoe, 14: 33-48.

Bothma, J. du P. (ed.) 2002. Game ranch management, 4th ed. Pretoria: Van Schaik.

Bothma, J. du P. \& Mills, M.G.L. 1977. Ungulate abundance in the Nossob River Valley, Kalahari Desert. Proceedings of the XIIIth International Congress of Game Biologists, Atlanta, Georgia, pp. 90-102.

Bothma, J. du P., Van Rooyen, N. \& Du Toit, J.G. 2002. Antelope and other smaller herbivores. In: Bothma, J. Du P. (ed.) 2002. Game ranch management, 4th ed. Pretoria: Van Schaik, pp. $149-175$

Child, D. \& Le Riche, J.D. 1969. Recent springbok treks (mass movements) in south-western Botswana. Mammalia, 33: 499-504.

Conroy, A.M. 2005. The springbok. In: Bothma, J. du P. \& Van Rooyen, N. (eds). Intensive wildlife production in southern Africa. Pretoria: Van Schaik, pp. 214-226.

Eloff, F.C. 1961. Observations on the migrations and habits of the antelope of the Kalahari Gemsbok Park, Part 3. Koedoe, 4: $18-30$.

Engelbrecht, D. dries@sanparks.org, 2002. Stapelberg, H, hein. staplberg@gmail.com, November 2002.

Hague, P. 1993. Questionnaire design. London: Kogan Page.

Jackson, T.P. 1995. The role of territoriality in the mating system of the springbok Antidorcas marsupialis (Zimmermann 1780). PhD dissertation, Pretoria: University of Pretoria.

Jackson, T.P., Skinner, J.D. \& Richardson, P.R.K. 1993. Some costs of maintaining a perennial territory in the springbok, Antidorcas marsupialis. African Journal of Ecology, 31(3): 242254.

Jeltsch, F., Milton, S.J., Dean, W.R.J. \& Van Rooyen, N. 1997. Simulated pattern formation around artificial waterholes in the semi-arid Kalahari. Journal of Vegetation Science, 8(2): 177-188.

Johnson, D.H. 1980. The comparison of usage and availability measurements for evaluating resource preference. Ecology, 61(1): 65-71.

Knight, M.H. 1995. Tsamma melons, Citrullus lanatus, a supplementary water supply for wildlife in the southern Kalahari. African Journal of Ecology, 33: 71-80.

Knight, M.H. \& Knight-Eloff, A.K. 1988. The importance of borehole water and lick sites for Kalahari South Africa ungulates. Journal of Arid Environments, 15: 269-282.

Leistner, O.A. 1959. Notes on the vegetation of the Kalahari Gemsbok National Park with special reference to its influence on the distribution of antelopes. Koedoe, 2: 128151.

Leistner, O.A. 1967. The plant ecology of the southern Kalahari. Memoirs of the Botanical Survey of South Africa, 38: 1-172.

Louw, G.N. \& Seely, M.K. 1982. Ecology of desert organisms. London: Longman.

Mills, M.G.L. \& Haagner, C. 1989. Guide to the Kalahari Gemsbok National Park. Johannesburg: Southern Book Publishers.

Mills, M.G.L. \& Retief, P.F. 1984. The response of ungulates to rainfall along the riverbeds of the southern Kalahari. Koedoe (Suppl.), 27: 129-141.

Nagy, K.A. \& Knight, M.H. 1994. Energy, water, and food use by springbok antelope (Antidorcas marsupialis) in the Kalahari desert. Journal of Mammalogy, 75: 860-872.

Peters, J. \& Brink, J.S. 1992. Comparative postcranial osteomorphology and osteometry of springbok Antidorcas marsupialis (Zimmermann, 1780) and grey rhebok, Pelea capreolus (Forster, 1790) (Mammalia: Bovidae). Memoirs of the National Museum Bloemfontein, 8: 161-207.

Siegfried, W.R. 1980. Vigilance and group size in springbok. Madoqua, 12: 151-154. 
Sinclair, A.R.E. \& Norton-Griffiths, M. 1982. Does competition or facilitation regulate migrant ungulate populations in the Serengeti? A test of hypotheses. Oceologia, 53(3): 364-369.

Skarpe, C. 1986. Plant community structure in relation to grazing and environmental changes along a north-south transect in the western Kalahari. Vegetatio, 68(1): 3-18.

Skarpe, C. 2001. Resource use and rangeland products. Available at: http://www.maposda.net/Global/reports/lesotho/ Session2b_Botswana_2.pdf [Accessed 2006].

Skinner, J.D. 1993. Springbok (Antidorcas marsupialis) treks. Transactions of the Royal Society of South Africa, 48: 291-305.

Skinner, J.D., john.skinner@up.ac.za, 2003. Stapelberg, H, hein. stapelberg@gmail.com, February 2003.

Skinner, J.D. \& Louw, G.N. 1996. The Springbok Antidorcas marsupialis (Zimmermann, 1780). Pretoria: Transvaal Museum.

Skinner, J.D. \& Moss, D.G. 2004. Kgalagadi springbok (Antidorcas marsupialis): bucking the trend. Transactions of the Royal Society of South Africa, 59(2): 119-121.

Skinner, J.D., Van Aarde, R.J., Knight, M.H. \& Dott, H.M. 1996. Morphometrics and reproduction in a population of springbok Antidorcas marsupialis in the semi-arid southern Kalahari. African Journal of Ecology, 34(3): 312-330.

Spinage, C.A. \& Matlhare, J.M. 1992. Is the Kalahari cornucopia fact or fiction? A predictive model. Journal of Applied Ecology, 29(3): 605-610.

Stapelberg, F.H. 2007. Feeding ecology of the Kalahari springbok Antidorcas marsupialis in the Kgalagadi Transfrontier Park, South Africa. MSc. Dissertation. Pretoria: University of Pretoria.

Stapelberg, F.H., Van Rooyen, M.W. \& Bothma, J. Du P. in press. Seasonal nutrient fluctuation of selected plant species in the Kalahari. African Journal of Range and Forage Science.

Taylor, C.R. 1968. Hygroscopic food: a source of water for desert antelope? Nature, 219(4): 181-182.

Treves, A. 2000. Theory and methods in study of vigilance and aggregation. Animal Behaviour, 60(6): 711-722.

Tyson, P.D. 1986. Climatic change and variability in southern Africa. Cape Town: Oxford.

Van Rooyen, N. 2001. Flowering plants of the Kalahari dunes. Pretoria: Ekotrust.

Van Rooyen, N., Bezuidenhout, D., Theron, G.K. \& Bothma, J. du P. 1990. Monitoring of the vegetation around artificial watering points (windmills) in the Kalahari Gemsbok National Park. Koedoe, 33(1): 63-88.

Van Rooyen, N., Bredenkamp, G.J., Theron, G.K., Bothma, J. du P. \& Le Riche, E.A.N. 1994. Vegetational gradients around artificial watering points in the Kalahari Gemsbok National Park. Journal of Arid Environments, 26(4): 349-361.

Van Rooyen, N. \& Van Rooyen, M.W. 1998. Vegetation of the south-western arid Kalahari: an overview. Transactions of the Royal Society of South Africa, 53(2): 113-140.

Williamson, D.T. 1987. Plant underground storage organs as a source of moisture for Kalahari wildlife. African Journal of Ecology, 25(1): 63-64.

\section{APPENDIX A}

Variables, listed in the questionnaire, that were recorded by staff, the researcher and visitors to the Kalahari Gemsbok National Park from November 2002 to May 2004 to study springbok behaviour in the park. Note that not all variables are reported on in this publication.

1. Date

2. Location

3. Time when observation starts

4. Total number of springbok

5. Riverbed habitat (yes or no)

6. Plains habitat (yes or no)

7. Duneveld (yes or no)
8. Pan-type habitat (yes or no)

9. Tree-dominated habitat (yes or no)

10. Grass-dominated habitat (yes or no)

11. Shrub-dominated habitat (yes or no)

12. Other (three alternative dominant habitat features recorded)

13. Near a camp (yes or no)

14. Near a waterhole (yes or no)

15. Near a picnic spot (yes or no)

16. Other (none specified)

17. Total number of blue wildebeest

18. Total number of red hartebeest

19. Total number of gemsbok

20. Total number of other species (13 other animal species recorded)

21. Distance between springbok and blue wildebeest (0-20 $\mathrm{m}, 21-50 \mathrm{~m}$ and $>50 \mathrm{~m}$ specified)

22. Distance between springbok and red hartebeest (0-20 $\mathrm{m}, 21-50 \mathrm{~m}$ and $>50 \mathrm{~m}$ specified)

23. Distance between springbok and gemsbok $(0-20 \mathrm{~m}$, 21-50 $\mathrm{m}$ and $>50 \mathrm{~m}$ specified)

24. Distance between springbok and other animal species (0-20 $\mathrm{m}, 21-50 \mathrm{~m}$ and $>50 \mathrm{~m}$ specified)

25. Percentage of the springbok herd feeding in sunlight*

26. Percentage of the springbok herd feeding in the shade*

27. Percentage of the springbok herd standing in sunlight*

28. Percentage of the springbok herd standing in shade*

29. Percentage of the springbok herd lying down in sunlight*

30. Percentage of the springbok herd lying down in shade*

31. Percentage of the springbok herd sleeping in sunlight*

32. Percentage of the springbok herd sleeping in shade*

33. Percentage of the springbok herd walking in sunlight*

34. Percentage of the springbok herd walking in shade*

35. Percentage of the springbok herd playing in sunlight*

36. Percentage of the springbok herd playing in shade*

37. Percentage of the springbok herd doing something else* (19 alternative actions recorded)

38. Percentage of the springbok herd feeding on grass*

39. Percentage of the springbok herd feeding on shrubs*

40. Percentage of the springbok herd feeding on trees*

41. Percentage of the springbok herd feeding on something else $^{*}$ (22 alternative options recorded)

42. Direction in which animals are moving (north, northeast, east, southeast, south, southwest, west and northwest specified)

43. Time when observation ends

44. Sheet number

45. Total number of male springbok in the herd ${ }^{\phi}$

46. Total number of female springbok in the herd

47. Total number of immature springbok in the herd ${ }^{\phi}$

48. Springbok are feeding on flowers (yes or no) ${ }^{\phi}$

49. Springbok are feeding on fruit (yes or no) ${ }^{\phi}$

50. Nearest waterhole ( 47 waterholes specified) ${ }^{\phi}$

51. Habitat type (four options specified) ${ }^{\phi}$

\section{Additional variables, only recorded by the researcher}

1. Springbok are feeding on fresh, new plant growth (yes or no)

2. Springbok are feeding on old plant growth (yes or no)

3. Wind direction (north, northeast, east, southeast, south, southwest, west and northwest specified)

4. Wind strength (none, breeze, moderate, strong, extreme)

*Numbers were converted into percentages of the total herd after collection. $\phi$ Although variables 45 to 51 did not appear on the questionnaire, they were recorded as additional notes by the researcher, as well as some of the visitors/ staff. 